\title{
New azooxanthellate genus of Scleractinia (Flabellidae) from the Australian Cenozoic
}

\author{
Stephen D. Cairns \\ Department of Invertebrate Zoology, National Museum of Natural History, Smithsonian Institution, Washington, DC 20560, USA 〈cairnss@ si.edu〉
}

\begin{abstract}
A new genus of flabellid scleractinian coral, Periplacotrochus, is described from the late Eocene to middle Miocene of Victoria, South Australia, and Tasmania. It differs from Placotrochus in having a pedicellate base, and from Flabellum in having a lamellar columella. Six previously described species are redescribed, illustrated, and reassigned to this genus $(P$. deltoideus Duncan, 1864, P. corniculatus Dennant, 1899, P. elongatus Duncan, 1864, P. pueblensis Dennant, 1903, P. inflectus Dennant, 1903, and P. magnus Dennant, 1904), and one new species is described: P. cudmorei. One species, Placotrochus elegans Tennison-Woods, 1878a, is considered as a nomen dubium. A key is provided to the seven species placed in this genus.
\end{abstract}

\section{Introduction}

Duncan (1864) noted that there were 'paired' flabellid genera, or maybe only groups of species, differing from one another by only one character, such as the presence or absence of a lamellar columella. He called these 'mimetic' genera, or those that mimic one another, except for one character. He also noted that groups of flabellid species might also differ from another by having a pedicellate (attached) base or having transverse division, being otherwise similar. He categorized 10 flabellid species into four permutations or categories (Fig. 1): (1) pedicellate and lacking a columella (typical Flabellum Lesson, 1831, Fig. 1, Category 1), (2) pedicellate but with a lamellar columella (unnamed higher taxon, herein Periplacotrochus, Fig. 1, Category 2), (3) transverse division and lacking a columella (future Truncatoflabellum Cairns, 1989b, Fig. 1, Category 3), and (4) transverse division but with a lamellar columella (typical Placotrochus Milne Edwards and Haime, 1848, Fig. 1, Category 4). Species in the third category mentioned in the preceding are quite common, represented by at least 38 species, occurring in water depths of $2-3,010 \mathrm{~m}$ around the world, as well as in the fossil record as early as the middle Eocene (Cairns, 2016). This group was frequently discussed (see Cairns, 1989b) but not named until 1989, when Cairns (1989a, b) suggested that transverse division conferred an evolutionary advantage to this genus. He called the genus Truncatoflabellum Cairns, 1989b. A similar situation occurs between Category 4 (Placotrochus) and Category two; however, because species belonging to Category two occur exclusively as fossils in southern Australia and are collected, this species group has never been named. Cairns (1989b, p. 75) had implied the need for such a name, calling this group of species the 'Placotrochus' deltoideus species complex (Cairns, 1989b, table 4). The purpose of this paper is to name this genus and redescribe the species contained in it.
According to Duncan (1864), the genus Flabellum could be considered mimetic to Truncatoflabellum, differing only in lacking transverse division. In the same way, Periplacotrochus could be considered mimetic to Flabellum, differing only in having a lamellar columella. Likewise, Truncatoflabellum could be considered mimetic to Placotrochus, differing only in lacking a lamellar columella, and Placotrochus could be considered mimetic to Periplacotrochus, differing only in having transverse division (Fig. 1). Whatever way interpreted, Flabellum is the oldest genus (Late Cretaceous) and could have been the ancestor of Periplacotrochus (earliest known occurrence lower Eocene) and Truncatoflabellum (earliest known occurrence middle Eocene). Placotrochus, known only from the Recent, could have evolved from either Periplacotrochus or Truncatoflabellum by one character state change.

Because of the solitary nature of the corallum and the placement of the genus in the family Flabellidae, species of Periplacotrochus are assumed to have been azooxanthellate. Because of its similarity to Placotrochus and Truncatoflabellum and other associated south Australian Cenozoic corals, especially those found at Muddy Creek and Balcombe's Bay, Victoria, the species of Periplacotrochus are assumed to have lived in the middle to lower shelf depths, i.e., 50-200 m.

\section{Materials and methods}

The terminology used in the descriptions is defined and illustrated in Cairns and Kitahara (2012). Abbreviations used in the text include the following: $\mathrm{Cx}, \mathrm{Sx}=$ costae or septa, respectively, of cycle $\mathrm{x} ; \mathrm{GCD}=$ greater calicular diameter; GCD: $\mathrm{LCD}=$ ratio of greater calicular diameter to lesser calicular diameter of a corallum; $\mathrm{H}: \mathrm{GCD}=$ ratio of corallum height to its greater calicular diameter; $\mathrm{Sx}>\mathrm{Sy}=$ in the context of a septal formula, septa of cycle $x$ are wider than those of cycle $y$. 


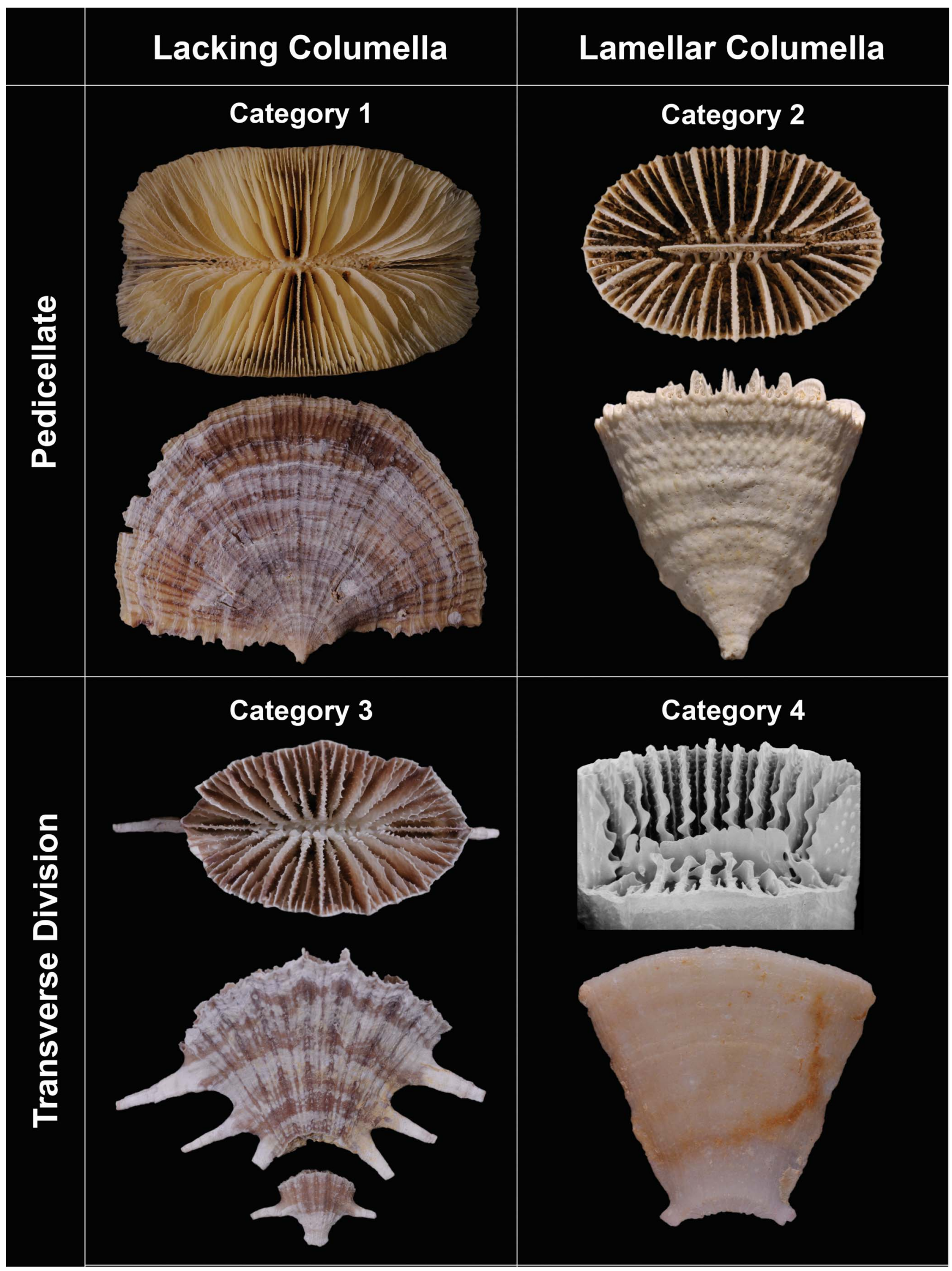


Table 1. Number of species and distribution of the 14 Recent and fossil flabellid genera.

\begin{tabular}{|c|c|c|}
\hline Genus & $\begin{array}{l}\text { Number of Recent species: geographic range; } \\
\text { depth range }\end{array}$ & $\begin{array}{l}\text { Number of fossil species: stratigraphic } \\
\text { range and occurrence }\end{array}$ \\
\hline Adkinsella Wells, 1933 & 0 & 1: lower Cretaceous (Texas) \\
\hline Blastotrochus Milne Edwards and Haime, 1848 & 1: Southwest Pacific; $11-62 \mathrm{~m}$ & 0 \\
\hline Conosmilia Duncan, 1865 & 0 & 6: middle Miocene (Victoria, Australia) \\
\hline Cycloflabellum Chevalier, 1961 & 0 & 1: lower Pliocene (Morocco) \\
\hline Falcatoflabellum Cairns, 1995 & 1: Southwest Pacific; 366-402 m & 0 \\
\hline Flabellum Lesson, 1830 & 42: Cosmopolitan; 36-3,186 m & 150: Upper Cretaceous-Pleistocene (worldwide) \\
\hline Javania Duncan, 1876 & 10: Cosmopolitan; 30-2,165 m & 3: Eocene-Miocene (Tonga, Italy) \\
\hline Monomyces Ehrenberg, 1834 & 2: Mediterranean, New Zealand; $5-410 \mathrm{~m}$ & 0 \\
\hline Periplacotrochus, n. gen. & 0 & 7: lower Eocene-middle Miocene (Victoria, Tasmania) \\
\hline Placotrochides Alcock, 1902 & 4: Indo-West Pacific; $80-1,628 \mathrm{~m}$ & 0 \\
\hline Placotrochus Milne Edwards and Haime, 1848 & 1: Indo-West Pacific; 6-289 m & 0 \\
\hline Polymyces Cairns, 1979 & 3: worldwide, except E. Atlantic; 69-1,203 m & 0 \\
\hline Rhizotrochus Milne Edwards and Haime, 1848 & 4: Indo-West Pacific; $0-1,050 \mathrm{~m}$ & 0 \\
\hline Truncatoflabellum Cairns, $1989 \mathrm{~b}$ & 32: worldwide, except W. Atlantic; 2-3,010 m & 6: middle Eocene-Pleistocene (New Zealand, SW Pacific) \\
\hline
\end{tabular}

Repositories and institutional abbreviations.-NHMUK: The Natural History Museum, UK, London; NMNH: National Museum of Natural History, Smithsonian Institution, Washington DC; NMV: National Museum of Victoria, Victoria, Australia; USGS: United States Geological Survey; USNM: United States National Museum (now the NMNH), Washington DC. Many of the specimens reported as new records herein originate from a gift to the Smithsonian from F. A. Cudmore in April 1923.

\section{Systematic paleontology}

Class Anthozoa Ehrenberg, 1834

Order Scleractinia Bourne, 1900

Family Flabellidae Bourne, 1905

Diagnosis.-Corallum solitary, fixed, free, or transversely dividing. Wall epithecal (neotenic condition), sometimes secondarily thickened with stereome. Epitheca usually smooth, lacking costae. Septa imperforate, composed of a single fan system of numerous closely spaced trabeculae, which produces a smooth axial edge. Pali, dissepiments, and synapticulae absent; paliform lobes present on one genus. Columella usually rudimentary or absent, but may be lamellar, papillose, or fascicular. Exclusively azooxanthellate.

Occurrence.-Lower Cretaceous to Recent: worldwide, including off Antarctica, 0-3,186 m.

Remarks.-The family was most recently revised by Cairns (1989b, table 4), who tabularized the characteristics of the various genera. Table 1 is an update and expansion of that compilation, the family now consisting of 14 genera: seven exclusively Recent, four exclusively fossil, and three having both components. 100 Recent species are known in the family (Cairns and Hoeksema, 2015, table 1), making it the fifth-most species-rich family among the 24 families that contain Recent species in the Scleractinia (Cairns, 1999), and containing about $7 \%$ of the living species. Approximately 174 fossil species are known (Table 1); however, the total number of fossil species in the approximately 85 families that contain fossil species is not well known, and thus similar ranking cannot be made for the fossil species.

In the first broadly based phylogenetic analysis of the Scleractinia using molecular sequencing, Kitahara et al. (2010) supported the monophyly of the family Flabellidae but found polyphyletic assemblages among the three multispecies genera they analyzed (i.e., Flabellum, Truncatoflabellum, Javania), implying that the morphological distinctions of these genera may not be accurate. However, Kitahara et al. (2010, p. 4), even though professing to include "species representing the full morphological spectrum of the family," included species from only four of the 10 Recent genera, and of course none from the four exclusively fossil genera. Furthermore, only one mitochondrial gene was used in the analysis, which is usually not considered to be adequate for phylogenetic analyses. Finally, their conclusion that the transversely dividing genera (e.g., Truncatoflabellum) were antecedent to those with a pedicellate base (e.g., Flabellum) contradicts the fossil record, wherein Flabellum has the oldest fossil occurrence. Thus, based on these three reasons, the morphological distinction of genera is favored in this paper and is the only one that can be used with fossils.

\section{Genus Periplacotrochus new genus}

1864 Placotrochus; Duncan, p. 163, 164, 166-167 (in part).

1884 Placotrochus; Duncan, p. 16 (in part).

1943 Placotrochus; Vaughan and Wells, p. 227 (in part).

1956 Placotrochus; Wells, p. F432 (in part).

1989b "Placotrochus" deltoideus species complex; Cairns, p. 44, 45.

Type species.-Placotrochus deltoideus Duncan, 1864, here designated.

Diagnosis.-Corallum solitary, shaped as a laterally compressed fan; edge spines lacking but may have low thecal crests.

Figure 1. The four permutations or categories of genera resulting from the character states of two characters: presence or absence of a lamellar columella and pedicellate vs. transverse division. (Category 1) Flabellum, exemplified by F. magnificum, USNM 81951. (Category 2) Periplacotrochus, exemplified by the holotype of P.cudmorei. (Category 3) Truncatoflabellum, exemplified by the neotype of T. candeanum, USNM 81963. (Category 4) Placotrochus, exemplified by P. laevis, USNM 81994. 
Table 2. Key to the species of Periplacotrochus.

\begin{tabular}{lc}
\hline 1. Septa hexamerally arranged in four or five cycles & 2 \\
1'. Septa arranged in multiples of 20 , or $27-32$ & 6 \\
2. Septa arranged in five cycles ( 96 septa) & P. deltoideus \\
2'. Septa arranged in four (or fewer) cycles (40-48 septa) & 3 \\
3. Corallum regularly curved (cornute) & P. corniculatus \\
3'. Corallum not cornute, but may be irregularly bent & P. elongatus \\
4. GCD:LCD $=1.5-1.67$ (calice outline elliptical in cross section) & 5 \\
4'. GCD:LCD $=1.02-1.115$ (calice almost circular) & P. pueblensis \\
5. Corallum with a full fourth cycle of septa (48) & P. inflectus \\
5'. Corallum lacking lateral pairs of S4 (40 septa) & P. cudmorei \\
6. Septa arranged in three size classes, including 20 primary septa (80 septa) & P. magnus \\
6'. Septa arranged in three size classes, including $27-32$ primary septa (104-128 total septa) & \\
\hline
\end{tabular}

Transverse division lacking; corallum fixed to fragment of substrate by small pedicel elliptical in cross section; pedicel not stereome reinforced. Pali and paliform lobes absent; lamellar columella prominent. Calicular edge smooth; septa often slightly exsert.

Occurrence.-Late Eocene to middle Miocene: Victoria, South Australia, Tasmania.

Etymology.-The Greek prefix peri, meaning near, prefaces Placotrochus to show its close relationship to that genus. Gender: masculine.

Remarks.-Periplacotrochus differs from Flabellum in having a lamellar columella, and from Placotrochus by being pedicellate (not transversely dividing). Key to the species of Periplacotrochus is shown in Table 2.

Periplacotrochus deltoideus (Duncan, 1864) new combination Figure 2.1-2.4

1864 Placotrochus deltoideus Duncan, p. 164, 167, pl. 5, fig. 5a-c.

1870 Placotrochus deltoideus; Duncan, p. 300, 309, 311, pl. 20, fig. 4a, b.

1875 Placotrochus deltoideus; Tenison-Woods, p. 17.

1876 Placotrochus deltoideus; Duncan, p. 341.

1878b Placotrochus deltoideus: Tenison-Woods, p. 315.

1878c Placotrochus deltoideus; Tenison-Woods, p. 65.

1927 Placotrochus deltoideus; Felix, p. 417.

1989b Placotrochus deltoideus; Cairns, p. 75, pl. 40, fig. a-c. Undated Placotrochus deltoideus; Fitzgerald and Schmidt, p. 3 (color illustration).

Types.-Five syntypes are deposited at the NHMUK (PI R29269-29273). Type locality: Muddy Creek, Victoria (Balcombian, middle Miocene).

Diagnosis.-Corallum with five cycles (96 septa) of hexamerally arranged septa.
Occurrence.-Janjukian (= Rupelian, late Oligocene): Torquay, Victoria. Balcombian (= Langhian, middle Miocene): Muddy Creek, Balcombe's Bay, and Beaumaris, Victoria. Miocene: northwestern Tasmania.

Description.-The corallum has a bimodal edge angle, the lower thecal edges making an angle of $71^{\circ}-87^{\circ}$, the upper thecal edges diverging at only $48^{\circ}-60^{\circ}$ (Fig. 2.1); the lower thecal edges are acute and usually bear a low, discontinuous crest (variety bursarius of Duncan, 1864). The thecal faces are planar (not convex), having a face angle of $30^{\circ}-39^{\circ}$. The largest corallum (USNM 67953, Fig. 2.1-2.4) is $27.2 \mathrm{~mm}$ in height and $27.2 \times 19.3 \mathrm{~mm}$ in calicular diameter. The calice is elliptical, the GCD:LCD ranging from 1.4 to 1.7 ; the $\mathrm{H}$ :GCD ranges from 1.0 to 1.1 . The greater axis of the small $(1.5-1.6 \times 0.95-1.0 \mathrm{~mm})$, elongate pedicel is aligned with the GCD. Each thecal face is ribbed with low $\mathrm{C} 1-3$ (Fig. 2.1).

Above a GCD of $20 \mathrm{~mm}$ the septa are consistently arranged in five complete cycles (Fig. 2.3-2.4): S1-3 > S4 > S5 (96 septa). Below that diameter, coralla have only 20-22 major septa (not 24) and a corresponding lesser number of higher cycle septa. The S1-3 have slightly sinuous axial edges, the lowermost edges fusing with the columella. The S4 are about half the width of the S1-3, and the S5 are rudimentary, but consistently present. The fossa is of moderate depth and contains a prominent lamellar columella, consisting of a single thick lamella.

Materials.-Muddy Creek (Clifton Bank), Victoria, middle Miocene, one corallum, USNM 67955 (topotypic). USGS 10674, Muddy Creek, Victoria, middle Miocene, eight coralla, USNM M353589 (topotypic). Balcombe's Bay, Victoria, Balcombian (middle Miocene), five coralla, USNM 67953 and USNM M353578. USGS 10809, Mornington, Balcombe's Bay, Victoria, middle Miocene, eight coralla, USNM 77072 and USNM M353921. USGS 10808, Torquay, Victoria, Janjukian (late Oligocene), six coralla, USNM M353590.

Remarks.-Periplacotrochus deltoideus is very similar to $P$. magnus, resembling a smaller version of that species. However, $P$. deltoideus can be distinguished by having a

Figure 2. (1-4) Periplacotrochus deltoideus, USNM 67953, Balcombe's Bay, Victoria, middle Miocene, lateral, edge, calicular, and oblique calicular views, respectively. (5-7) P. corniculatus, holotype, NMV P27069, lateral, edge, and calicular views, respectively. (8-12) P. elongatus, USNM 10674, Muddy Creek, Victoria, middle Miocene: (8) specimen showing lamellar columella; (9-12) lateral, edge, calicular, and oblique calicular views of same specimen. (13-15) $P$. pueblensis, holotype, NMV P27106, lateral, edge, and calicular views, respectively. (1-6, 8-14) Scale bars $=10 \mathrm{~mm} ;(\mathbf{7}, \mathbf{1 5})$ scale bars $=5 \mathrm{~mm}$. 

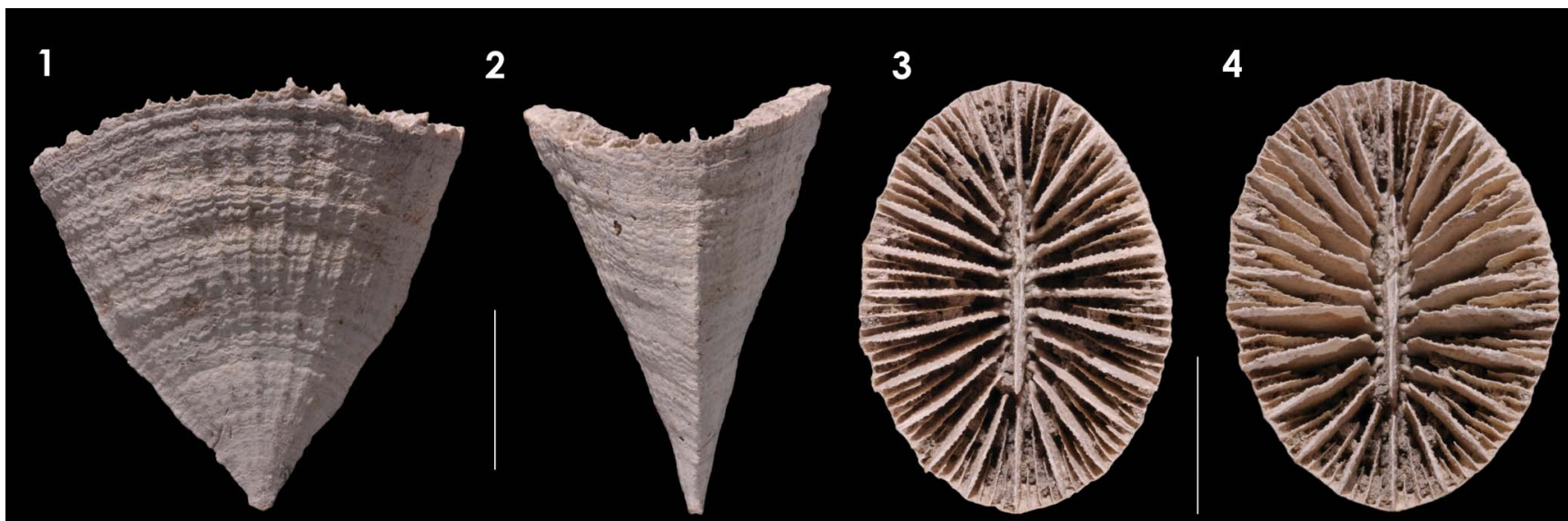

5

6
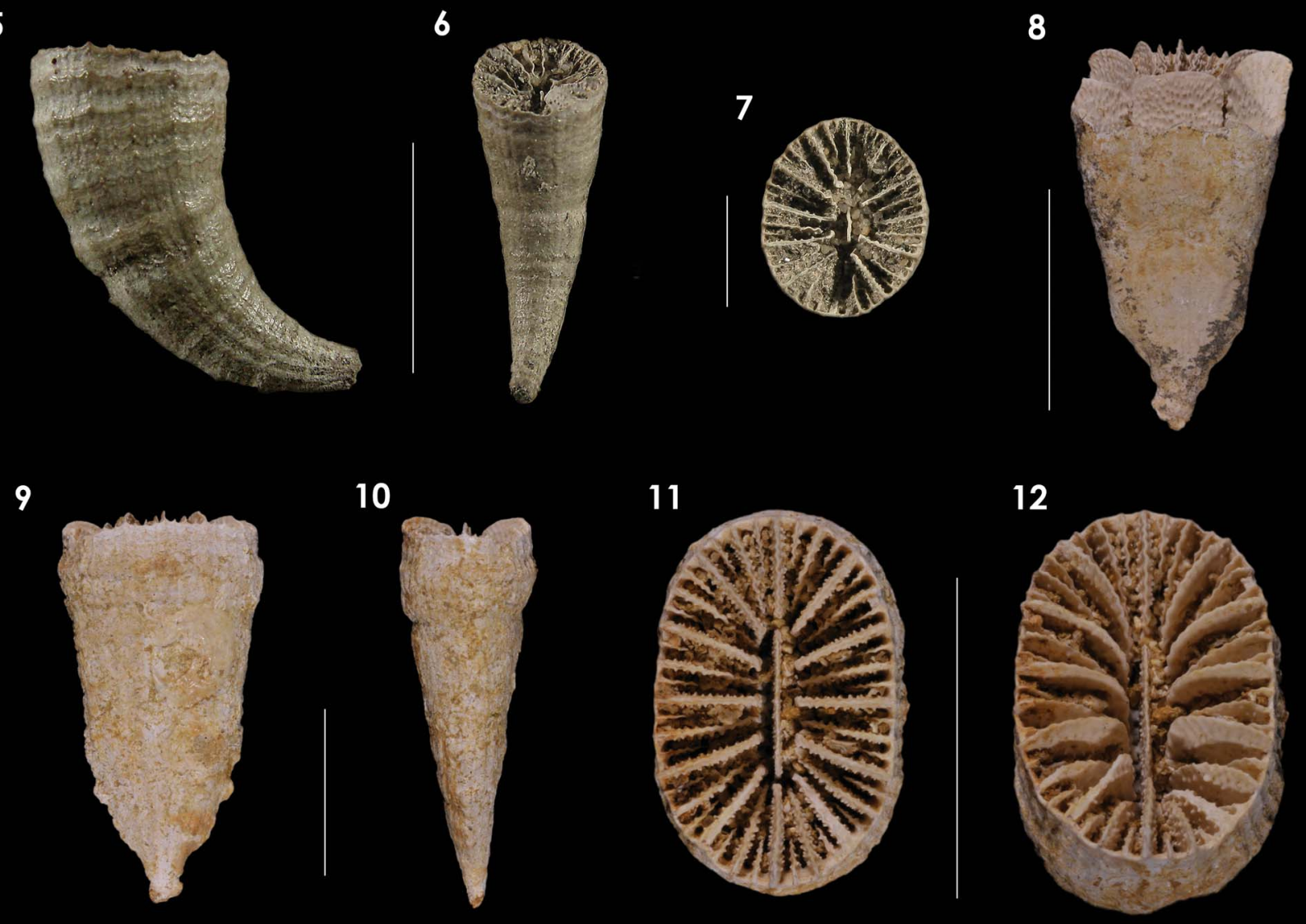

13

14
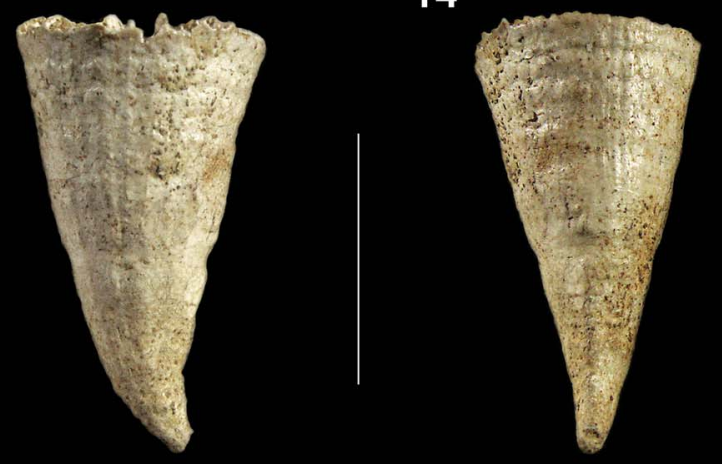

15

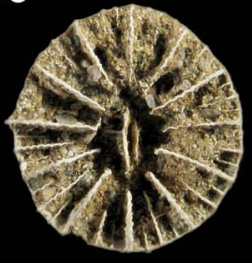


smaller corallum, straight (not convex) thecal faces and thus a less full corallum, consistently 96 hexamerally arranged septa (vs. three size classes of septa, the largest counting 28-32), consistently crested lower thecal edges, and ribbed $\mathrm{C} 1-3$.

\section{Periplacotrochus corniculatus (Dennant, 1899) new combination}

Figure 2.5-2.7

1899 Placotrochus corniculatus Dennant, p. 115, pl. 2, fig. 3a-b.

1927 Placotrochus corniculatus; Felix, p. 416.

1981 Placotrochus corniculatus; Bell, p. 11 (type deposition). 1989b Placotrochus corniculatus; Cairns, p. 75 (mentioned).

Types.-Holotype deposited at the NMV (P27069); paratype NMV P27070 (Blanche Point); Dennant (1899) mentioned a third specimen, which would also be a paratype. Type locality: Adelaide bore, South Australia, Miocene according to Felix (1927).

Diagnosis.-Corallum with four cycles (48 septa) of hexamerally arranged septa; corallum cornute.

Occurrence.-Known only from the type locality.

Description.-This species is known only from three specimens. The holotype is a cornute specimen (Fig. 2.5), curved about $75^{\circ}$. It is $20 \mathrm{~mm}$ in height and $9.0 \times 6.5 \mathrm{~mm}$ in calicular diameter, having a H:GCD of 2.2. The GCD:LCD range of the type series is $1.21-1.56$. The edge angle is about $13^{\circ}$; the face angle could not be computed from the figures or text. The septa are arranged in four complete cycles: $\mathrm{S} 1-2>\mathrm{S} 3>\mathrm{S} 4$ (48 septa). The S1-2 are slightly exsert with strongly sinuous axial edges. The $\mathrm{S} 3$ are almost as wide as the $\mathrm{S} 1-2$, and the $\mathrm{S} 4$ are relatively small. The fossa contains a typical lamellar columella.

Remarks.-This species is distinguished from the others in the genus by having a regularly curved (cornute) corallum (see Key in Table 2).

Periplacotrochus elongatus (Duncan, 1864) new combination Figure 2.8-2.12

1864 Placotrochus elongatus Duncan, p. 163, 167, pl. 5, fig. 4a-e.

1870 Placotrochus elongatus; Duncan, p. 300, 311, 312, 313, pl. 20, fig. 3a-c.

1878b Placotrochus elongatus; Tenison-Woods, p. 314.

1927 Placotrochus elongatus; Felix, p. 417.

1989b Placotrochus elongatus; Cairns, p. 75.

Types.-The holotype is deposited at the NHMUK (PI R29274). Type locality: Muddy Creek, Victoria (middle Miocene).

Diagnosis.-Corallum with four cycles (48 septa) of hexamerally arranged septa; corallum straight to irregularly bent (but not cornute); calice elliptical in cross section.
Occurrence.-Janjukian (late Oligocene): Torquay, Victoria. Balcombian (middle Miocene). Muddy Creek, Aire River, Grice's Creek, Victoria. Miocene: Table Cape, Tasmania, Mount Gambier, Cape Otway, Victoria.

Description.-The corallum is shaped as an isosceles triangle (Fig. 2.9), the edge angle ranging from $17^{\circ}-29^{\circ}$ and the thecal edges being straight. The thecal faces are planar (not convex), having a face angle of $12^{\circ}-22^{\circ}$ (Fig. 2.10). The lower thecal edges are acute but not crested; the upper thecal edges are evenly rounded, producing an elliptical calice having a GCD: LCD of 1.50-1.67. The H:GCD ranges from 1.6 to 3.2 , thus the name elongatus. One of the larger coralla (USNM 77069) measures $11.3 \times 7.3 \mathrm{~mm}$ in calicular diameter and $22.3 \mathrm{~mm}$ in height. The pedicel is small, about $1.9 \times 1.0 \mathrm{~mm}$ in diameter, the longer axis aligned with the GCD.

The septa are hexamerally arranged in four complete cycles: $\mathrm{S} 1-2>\mathrm{S} 3>\mathrm{S} 4$ (48 septa), even in coralla as small as $6.0 \mathrm{~mm}$ GCD. S1-2 are exsert, their axial edges quite sinuous, and their lower axial edges fused to the lamellar columella. The S3 are about four-fifths the width of the S1-2, much less sinuous, and they fuse with the columella. The $\mathrm{S} 4$ are two-thirds the width of the S3, their axial edges not attaining the columella. The fossa is deep and contains a prominent sharp lamellar columella, characteristic of the genus (Fig. 2.11, 2.12).

Materials.-USGS 10674, Muddy Creek, Victoria, Balcombian (middle Miocene), 39 coralla, USNM 77069 (topotypic). Clifton Bank, Muddy Creek, Victoria, Balcombian, eight coralla, USNM 67956 (topotypic). Grice's Creek (near Frankston), Victoria, Balcombian, six coralla, USNM M353579. Sunnyside Beach (Grice's Creek), Mornington, Victoria, Balcombian, 1 corallum, USNM 1283880. USGS 10808, Torquay, Janjuk Creek, Janjukian (late Oligocene), one corallum, USNM 1283878. Bird Rock Cliff, Torquay, Janjukian, two coralla, USNM 1283879.

Remarks.-Periplacotrochus elongatus is easily distinguished from other species by its elongate slender corallum (GCD: $\mathrm{H}=1.6-3.2$ ) (see also the Key in Table 2).

Periplacotrochus pueblensis (Dennant, 1903) new combination Figure 2.13-2.15

1903 Placotrochus pueblensis Dennant, p. 212, pl. 2, fig. 1a-b. 1981 Placotrochus pueblensis; Bell, p. 11 (type deposition). 1989b Placotrochus pueblensis; Cairns, p. 75 (mentioned).

Types.-The holotype is deposited at the NMV (P27106). Type locality: Spring Creek (The Ledge), Victoria, Janjukian (late Oligocene).

Diagnosis.-Corallum with four cycles (48 septa) of hexamerally arranged septa; corallum straight to irregularly bent (but not cornute); calice round in cross section.

Occurrence.-Known only from the type locality. 
Description.-The species is known from only one specimen, the holotype. It is essentially conical (Fig. 2.13, 2.14): $17.8 \mathrm{~mm}$ tall (as measured from the figure) and $10.4 \times 10.2 \mathrm{~mm}$ (as measured from the figure) in calicular diameter (GCD: $\mathrm{LCD}=1.02$, essentially circular). The angle of thecal divergence is uniformly about $27^{\circ}$. The epitheca is porcellaneous. The septa are arranged in four complete cycles: $\mathrm{S} 1-2>\mathrm{S} 3>\mathrm{S} 4$ (48 septa). The S1-2 are slightly exsert, whereas the S3 are about three-fourths the width of the S1-2, and the S4 are about half the width of the $\mathrm{S} 3$. The fossa is deep, containing a somewhat unusual (?aberrant) double-lamellar columella (Fig. 2.15).

Remarks.-Periplacotrochus pueblensis is distinctive in having a circular calice and 48 septa, although it is very similar to $P$. inflectus, as described in the account of that species (see also Key to species in Table 2).

Periplacotrochus inflectus (Dennant, 1903) new combination Figure 3.1-3.4

1903 Placotrochus inflectus Dennant, p. 213, pl. 2, fig. 2a-c. 1981 Placotrochus inflectus; Bell, p. 11 (type deposition). 1989b Placotrochus inflatus (sic); Cairns, p. 75.

Types.-Four syntypes are deposited at the NMV (P27107 and 27108), see Bell (1981). Two additional specimens (?syntypes) are also deposited at that museum: P134078 and P146120. Type locality: "Eocene clays at Brown's Creek, Aire R. district" (Dennant, 1903, p. 213), Victoria, middle to late Eocene.

Diagnosis.-Corallum with four cycles of hexamerally arranged septa but lacking eight S4, resulting in 40 septa; corallum straight to irregularly bent (but not cornute); calice round in cross section.

Occurrence.-Known only from the type locality.

Description.-The species is known from only four specimens, two of them poorly preserved. The specimen described and illustrated by Dennant (1903) is ceratoid (almost conical, Fig. 3.1, 3.2), $7.5 \times 6.5 \mathrm{~mm}$ in calicular diameter (GCD:LCD $=1.15)$, and $16 \mathrm{~mm}$ in height $(\mathrm{H}: \mathrm{GCD}=2.13)$. The edge angle is about $23^{\circ}$. The epitheca is porcellaneous and the $\mathrm{C} 1-2$ are slightly raised. The pedicel attachment is elongate, as is typical for the genus. The septa are arranged in four cycles (S1$2>$ S3 $>$ S4), but the fourth cycle is incomplete, lacking four pairs of S4 in the lateral half systems, thus resulting in only 40 septa. The S1-2 are thick, their axial edges fused to the columella. The S3 and S4 are much thinner, the S3 about threefourths the width of the S1-2, and the S4 small. The lamellar columella is prominent (Fig. 3.3, 3.4).

Remarks.-Periplacotrochus inflectus is very similar to $P$. pueblensis and may simply represent an earlier ontogenetic stage in which the corallum is slightly smaller and thus has an incompletely developed fourth cycle of septa. Most other characters are similar or the same. However, the stratigraphic occurrence of $P$. inflectus is much earlier (middle to late Eocene) than that of $P$. pueblensis (late Oligocene). Clearly, more specimens are needed to resolve this distinction.

\section{Periplacotrochus cudmorei new species}

Fig. 3.5-3.8

Types.-Holotype: Clifton Bank, Muddy Creek, Victoria, Balcombian (middle Miocene), USNM 1283876. Paratypes: same locality as holotype, two, USNM 1283875. Bird Rock Cliffs, Torquay, Victoria, Janjukian (late Oligocene), four, USNM M353583. Spring Creek, Torquay, Victoria, Janjukian (late Oligocene), three, USNM 1283874. Type locality: Clifton Bank, Muddy Creek, Victoria, Balcombian (middle Miocene).

Diagnosis.-Septa arranged in three size classes, having 20 primary septa and thus 80 septa.

Occurrence.-Balcombian (middle Miocene): Muddy Creek, Victoria. Janjukian (late Oligocene): near Torquay, Victoria.

Description.-The corallum is triangular in lateral view (Fig. 3.5), the thecal edges forming an angle of $38^{\circ}-62^{\circ}$ and the planar faces forming a lesser angle of $30^{\circ}-38^{\circ}$ (Fig. 3.6). The lower thecal edges are acute and bear low crests, whereas the upper thecal edges are rounded. The holotype measures $18.2 \times$ $11.7 \mathrm{~mm}$ in calicular diameter and is $20.0 \mathrm{~mm}$ in height. The GCD:LCD ranges from 1.42 to 1.68 , and the H:GCD ranges from 0.8 to 1.1 but is usually over 1.0. The greater axis of the elongate (1.6-1.9 x 0.7-1.1 mm in diameter) pedicel attachment is aligned with the GCD. The 20 costae on the thecal faces are sometimes slightly elevated.

The septa are consistently arranged in three size classes: 20:20:40, resulting in 80 septa. The primaries are exsert as much as $1.5 \mathrm{~mm}$ and have moderately sinuous axial edges, their lower axial edges fusing to the lamellar columella. The secondary septa are about two-thirds the width of the primaries, have less sinuous axial edges, and do not reach the columella. The tertiaries are rather small. The fossa is shallow and contains a prominent lamellar columella (Fig. 3.7, 3.8).

Etymology.-Named in honor of Francis Alexander Cudmore (1892-1956), enthusiastic marine paleontologist who collected in Victoria and Tasmania and provided most of the Australian Tertiary corals donated to the Smithsonian in 1923.

Remarks.-This species is unique in having decameral septal symmetry (see Key in Table 2).

Periplacotrochus magnus (Dennant, 1904) new combination Figure 3.9-3.16

1904 Placotrochus magnus Dennant, p. 54, pl. 22, fig. 4a-c. 1981 Placotrochus magnus; Bell, p. 11 (type deposition). 1989b Placotrochus magnus; Cairns, p. 75 (mentioned).

Types.-The holotype (P27114) and paratype (P27115) are deposited at the NMV. Type locality: Spring Creek (16 miles south of Geelong), Victoria, Australia, Janjukian (late Oligocene). 
1

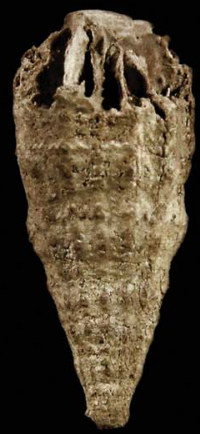

5

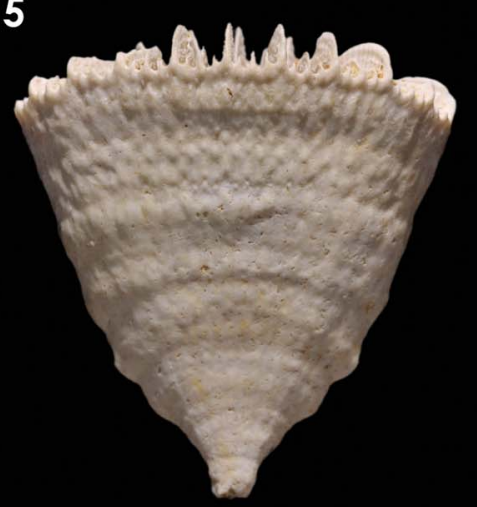

2

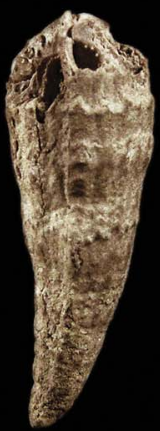

6

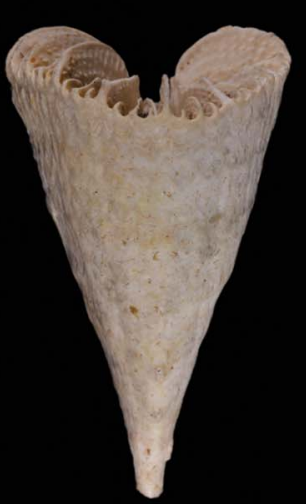

3

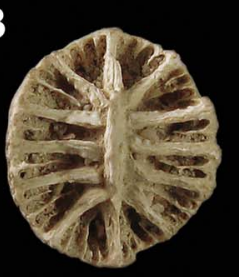

7

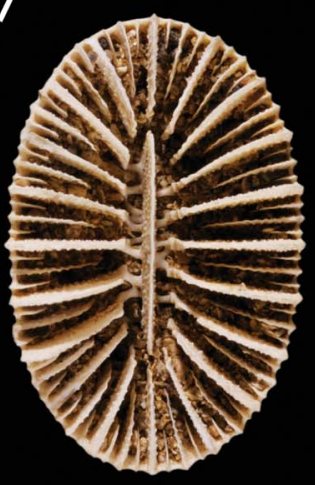

4

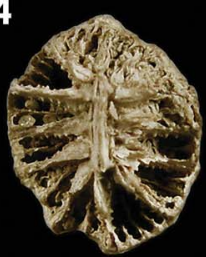

8

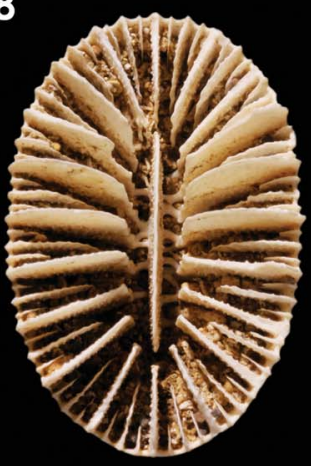

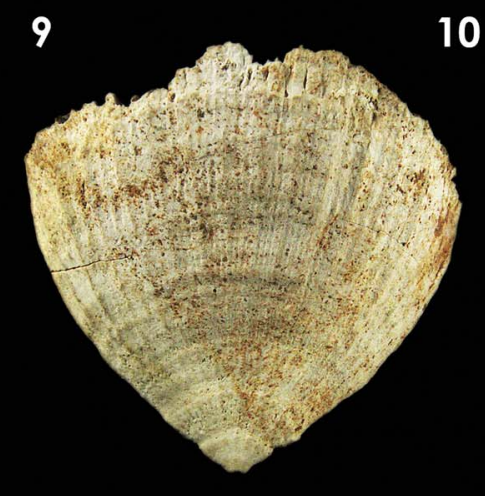

10

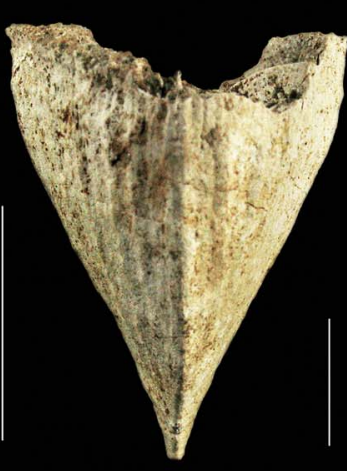

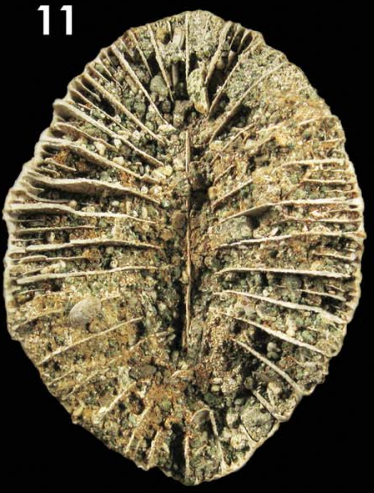

15
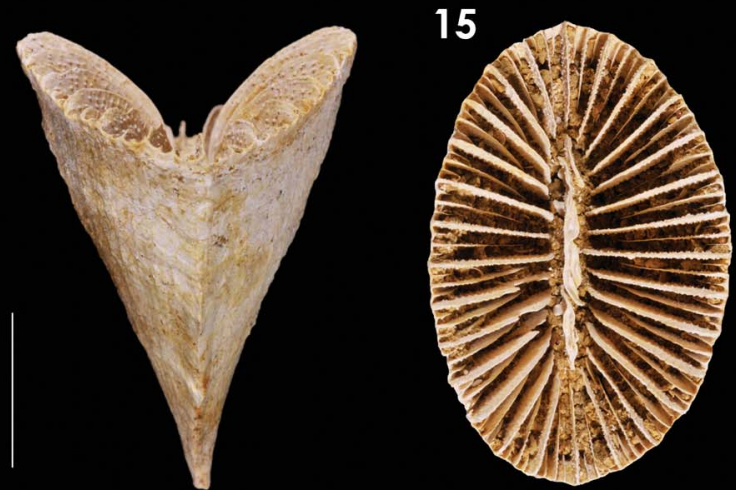
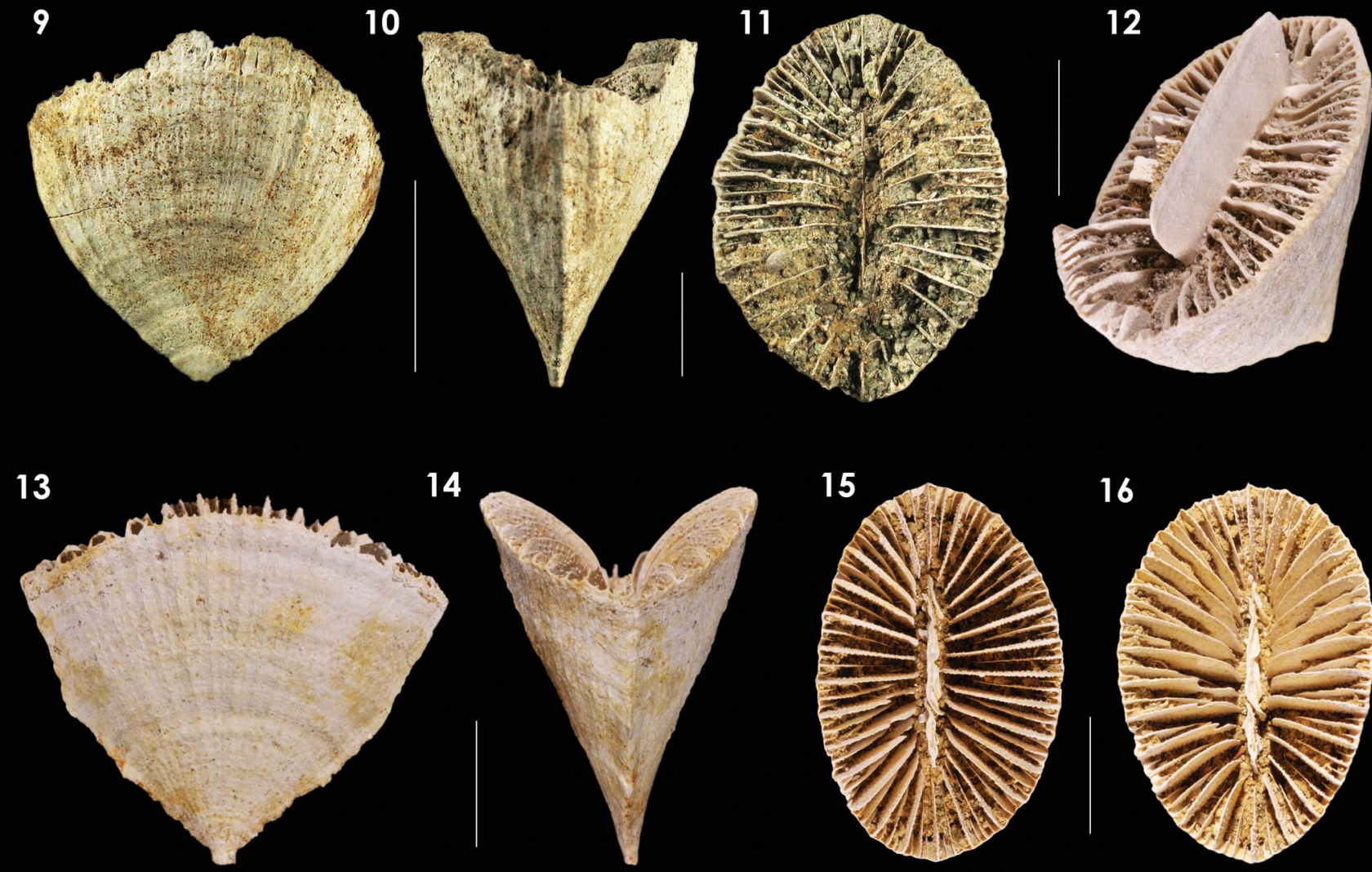

16

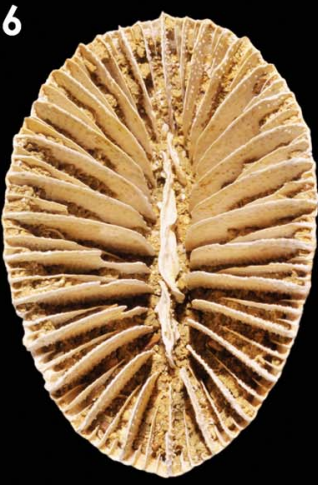




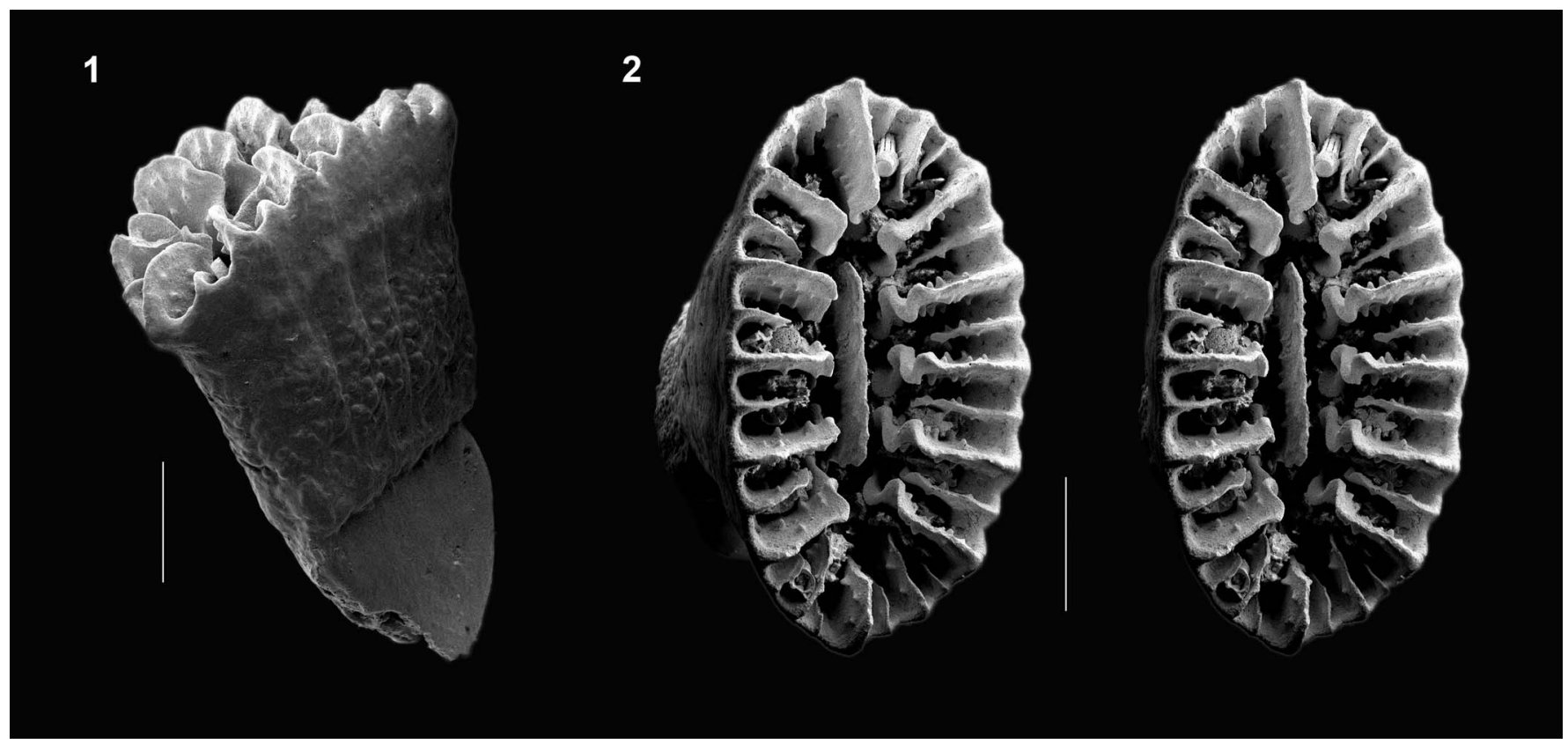

Figure 4. Juvenile specimen of Periplacotrochus, similar to that described as P. elegans, USNM 67999, Muddy Creek, Victoria, middle Miocene: (1) lateral view of specimen showing characteristic broad attachment to a shell fragment; (2) stereo view of calice showing 32 septa. Scale bars $=1 \mathrm{~mm}$.

Diagnosis.- Septa arranged in three size classes, but with 27-32 primary septa, resulting in 104-128 septa.

Occurrence.—Janjukian (late Oligocene): Torquay and Spring Creek (near Geelong), Victoria, Australia.

Description.-The corallum has a bimodal edge angle, the lower thecal edges making an angle of $91^{\circ}-98^{\circ}$ (Fig. 3.9, 3.13), whereas the upper thecal edges diverge at only $34^{\circ}-46^{\circ}$; the lower thecal edges are acute and bear a low crest, whereas the upper thecal edges are less acute and rounded near the calice. The thecal faces are planar to slightly convex, making a face angle of $36^{\circ}-45^{\circ}$ (Fig. 3.10, 3.14). The largest corallum (the holotype) is $37 \times 26 \mathrm{~mm}$ in calicular diameter and $33 \mathrm{~mm}$ in height. The calice is elliptical, the GCD:LCD ranging from 1.36 to 1.66; the H:GCD ranges from 0.89 to 1.21 . The pedicel is small $(1.8-2.0 \times 0.75-1.05 \mathrm{~mm})$, the greater axis aligned with the GCD.

The septa are arranged in three size classes, the holotype having septa arranged as 28:28:56 (112 septa), but other coralla have 27-32 primaries and a total of 104-128 septa. The primary septa are slightly exsert and have slightly sinuous axial edges, the lowermost edges fusing to the lamellar columella. The secondaries are about half the width of the primaries and do not attain the columella. The tertiaries are small to rudimentary but consistently present over a GCD of about $30 \mathrm{~mm}$. The fossa is of moderate depth and contains a prominent lamellar columella, usually consisting of a single, thick $(0.5 \mathrm{~mm})$ lamella (Fig. 3.12), but sometimes as two or three aligned lamellae (Fig. 3.15, 3.16).
Materials.-Torquay (near Geelong), Victoria, Janjukian (late Oligocene), two coralla, USNM 67954. Spring Creek (also known as Bird Rock Cliffs), Janjukian (late Oligocene), four coralla, USNM 67952.

Remarks.-Periplacotrochus magnus is compared to the closely related $P$. deltoideus in the account of the latter species.

\section{Periplacotrochus elegans Tenison-Woods, 1878a, nomen dubium}

1878a Placotrochus elegans Tenison-Woods, p. 189, pl. 1, fig. 1, 1a.

1927 Placotrochus elegans; Felix, p. 417.

1971 Placotrochus elegans; Fletcher, p. 32.

1989b Placotrochus elegans; Cairns, p. 75.

Types.-Holotype deposited at the Australian Museum (F.1697) (Fletcher, 1971). Type locality: Muddy Creek, Victoria, Balcombian (middle Miocene).

Diagnosis. - The species cannot be diagnosed as it is probably a juvenile stage of another species.

Occurrence.-Known only from the type locality.

Description.-The holotype is only $3 \mathrm{~mm}$ tall, with a compressed calice $(3.0 \times 1.5 \mathrm{~mm}$ in diameter, GCD:LCD $=2 ; \mathrm{H}$ : GCD $=1)$ and an elongate basal attachment $(1.65 \mathrm{~mm}$ in greater diameter). The edge angle is about $21^{\circ}$. According to

Figure 3. (1-4) Periplacotrochus inflectus: $(\mathbf{1}, \mathbf{2}, \mathbf{4})$ NMV P27107, syntype, lateral, edge, and calicular views, respectively; (3) calicular view of specimen NMV P134078. (5-8) P. cudmorei, holotype, USNM 1283876, lateral, edge, calicular, and oblique calicular views, respectively. (9-16) P. magnus: (9-11) holotype, NMV P27114, lateral, edge, and calicular views, respectively; (12) USNM 67954, damaged specimen showing its lamellar columella; (13-16) USNM 67954, lateral, edge, calicular, and oblique calicular views of same specimen, respectively. $(\mathbf{1}, \mathbf{2}, \mathbf{5}-\mathbf{1 6})$ Scale bars $=10 \mathrm{~mm} ;(\mathbf{3}, \mathbf{4}) \mathrm{scale}$ bars $=5 \mathrm{~mm}$. 
Tenison-Woods' (1878a) illustration, there are 16 larger septa and 16 smaller septa and a prominent lamellar columella.

Remarks.-The species is known from only one small specimen, undoubtedly the juvenile stage of a larger specimen, which shows the characteristic basal attachment of a Periplacotrochus. Three species of Periplacotrochus are known from the fossil beds of Muddy Creek, Victoria ( $P$. elongatus, $P$. deltoideus, and $P$. cudmorei), and this juvenile specimen could be any of these three. A specimen of similar size and shape is shown herein as Figure 4.1 and 4.2. It is therefore suggested to treat the name as a nomen dubium, as defined by the International Code of Zoological Nomenclature (article 75.5).

\section{Acknowledgments}

I thank F. Holmes and R. Schmidt (National Museum of Victoria, Melbourne) for permission to study the Dennant types deposited at that museum and for providing images of those specimens. I also thank R. H. Ford for photographing the NMNH specimens and composing them into Figures 1-4.

\section{References}

Alcock, A., 1902, Report on the deep-sea Madreporaria of the Siboga-Expedition: Siboga-Expeditie, v. 16a, p. 1-52.

Bell, K.N., 1981, A list of the Tertiary coral types in the National Museum of Victoria: Fossil Cnidaria, v. 10, p. 9-11.

Bourne, G.C., 1900, The Anthozoa, in Lankester, E.R., ed., A Treatise on Zoology, London, A. \& C. Black, chapter 6, p. 1-80.

Bourne, G.C., 1905, Report on the solitary corals collected by Professor Herdman, at Ceylon, in 1902: Ceylon Pearl Oyster Fisheries, Supplementary Reports, v. 29, p. 187-242.

Cairns, S.D., 1979, The deep-water Scleractinia of the Caribbean and adjacent waters: Studies on the fauna of Curaçao and other Caribbean Islands, v. 57, p. 1-341.

Cairns, S.D., 1989a, Asexual reproduction in solitary Scleractinia: Proceedings of the 6th International Coral Reef Symposium, Australia, v. 2, p. 641-646.

Cairns, S.D., 1989b, A revision of the ahermatypic Scleractinia of the Philippine Islands and adjacent waters, Part 1: Fungiacyathidae, Micrabaciidae, Turbinoliinae, Guyniidae, and Flabellidae: Smithsonian Contributions to Zoology, v. 486, p. 1-136.

Cairns, S.D., 1995, The marine fauna of New Zealand; Scleractinia (Cnidaria: Anthozoa): New Zealand Oceanographic Institute Memoir, v. 103, p. 1-210.

Cairns, S.D., 1999, Species richness of Recent Scleractinia: Atoll Research Bulletin, v. 459 , p. $1-12$

Cairns, S.D., 2016, A key to the genera and species of the transversely-dividing Flabellidae (Anthozoa, Scleractinia, Flabellidae), with a guide to the literature, and the description of two new species: ZooKeys, v. 562, p. 1-48.

Cairns, S., and Hoeksema, B., 2015, Flabellidae: World Register of Marine Species http://www.marinespecies.org/aphia.php?p=taxdetails\&id=135075 (accessed March 9, 2016).

Cairns, S.D., and Kitahara, M.V., 2012, An illustrated key to the genera and subgenera of the Recent azooxanthellate Scleractinia (Cnidaria, Anthozoa), with an attached glossary: ZooKeys, v. 227, p. 1-47.

Chevalier, J.P., 1961, Recherches sur les Madréporaires et les formations récifales Miocène de la Méditerranèe occidentale: Mémoires de la Societé geologique de France, new series, v. 40, p. 1-562.
Dennant, J., 1899, Descriptions of new species of corals from the Australian Tertiaries. Part 1: Transactions of the Royal Society of South Australia, v. 23 , p. $112-122$.

Dennant, J., 1903, Descriptions of new species of corals from the Australian Tertiaries. Part 6: Transactions of the Royal Society of South Australia, v. 27 , p. $208-215$.

Dennant, J., 1904, Descriptions of new species of coral from the Australian Tertiaries: Transactions of the Royal Society of Southern Australia, v. 28, p. 52-76.

Duncan, P.M., 1864, A description of some fossil corals and echinoderms from the south-Australian Tertiaries: The Annals and Magazine of Natural History, series 3, v. 14, p. 161-168.

Duncan, P.M., 1865, A description of some fossil corals from the South Australian Tertiaries: Annals and Magazine of Natural History, ser. 3, v. 6 , p. $182-187$.

Duncan, P.M., 1870, On the fossil corals (Madreporaria) of the Australian Tertiary deposits: : Quarterly Journal of the Geological Society of London, v. 26, p. 284-318.

Duncan, P.M., 1876, On some fossil reef-building corals from the Tertiary deposits of Tasmania: Quarterly Journal of the Geological Society, v. 31 , p. $341-351$.

Duncan, P.M., 1884, A revision of the families and genera of the Sclerodermic Zoantharia Ed. and H., or Madreporaria (M. Rugosa excepted): Journal of the Linnean Society of London, Zoology, v. 18, p. 1-204.

Ehrenberg, C.G., 1834, Beitrage zur Physiologischen Kenntniss der Corallenthiere im Allgemeinen und besonders des Rothen Meeres: Abhandlungen der Koniglichen Academie des Wissenschaften zu Berlin, v. 1832 , p. $225-380$.

Felix, J.P., 1927, Part 35: Anthozoa Miocaenica, in Deiner, C., ed., Fossilium Catalogus I: Animalia, Berlin, W. Junk, p. 297-488.

Fitzgerald, E., and Schmidt, R., undated, Fossils of Beaumaris, Melbourne, Museum of Victoria, $15 \mathrm{p}$.

Fletcher, H.O., 1971, Catalogue of type specimens in the Australian Museum, Sydney: Memoir 13, Sydney, The Australian Museum, p. $1-35$.

Kitahara, M.V., Cairns, S.D., Stolarski, J., Blair, D., and Miller, D.J., 2010 , A comprehensive phylogenetic analysis of the Scleractinia (Cnidaria, Anthozoa) based on mitochondrial CO1 sequence data: PLoS One, 5, e11490 doi:10.1371/journal.pone0011490.

Lesson, R.-P., 1831, Illustrations de Zoologie: Arthus Bertrand, LibraireEditeur, Paris, 3 p.

Milne Edwards, H., and Haime, J., 1848, Recherches sur les Polypiers, deuxième mémoire: Monographie des Turbinolides: Annals des Sciences Naturelles, Zoologie, ser. 3, v. 9, p. 211-344.

Tenison-Woods, J.E., 1875, On some Tertiary fossils from the Table Cape: Proceedings of the Royal Society of Tasmania for 1875, p. 13-26.

Tenison-Woods, J.E., 1878a, On some Australian Tertiary corals: Proceedings of the Royal Society of New South Wales, v. 11, p. 183-195.

Tenison-Woods, J.E., 1878b, On the extratropical corals of Australia: Proceedings of the Linnean Society of New South Wales, v. 2, p. 292-341.

Tenison-Woods, J.E., 1878c, On the Tertiary deposits of Australia: Journal and Proceedings of the Royal Society of New South Wales, v. 11, p. 65-82.

Vaughan, T.W., and Wells, J.W., 1943, Revision of the Suborders, Families, and Genera of the Scleractinia: Geological Society of America Special Paper, v. 44, p.xv 1-363.

Wells, J.W., 1933, Corals of the Cretaceous of the Atlantic and Gulf Coastal Plains and Western Interior of the United States: Bulletins of American Paleontology, v. 18, p. 85-288.

Wells, J.W., 1956, Scleractinia, in Moore, R.C., ed., Treatise on Invertebrate Paleontology, Part F: Coelenterata, New York, Geological Society of America and University of Kansas Press, p. F328-F498.

Accepted 4 May 2016 